\title{
Effect of potassium on growth, yield and quality of pineapple in tropical peat
}

A.H.M. Razzaque ${ }^{a \star}$, Mohamed Musa Hanafi ${ }^{b}$

a Crop Physiology Division, Bangladesh Institute of Nuclear Agriculture, P.O. Box \# 4,

Mymensingh-2200,

Bangladesh

(e-mail: bina@bdmail.net)

b Department of Land Management,

Faculty of Agriculture, Universiti Putra Malaysia, 43400 UPM, Serdang,

Selangor, Malaysia

\section{Effect of potassium on growth, yield and quality of pineapple in tropical peat.}

Abstract - Introduction. Two field experiments were conducted to investigate the effects of potassium (K) on plant growth, fruit yield and quality of pineapple cultivated on tropical peat soil. Materials and methods. Six levels of K: 0, 266, 532, 798, 1064 and $1330 \mathrm{~kg} \cdot \mathrm{ha}^{-1}$ $\mathrm{K}_{2} \mathrm{O}$ were applied at each of two pineapple plantations located at two different sites. The experiments were conducted with the Gandul cv. in a randomized complete block design with three replications. Results and discussion. The application of $\mathrm{K}$ had not any significant effect on plant height and leaf number of pineapple at both sites. Potassium significantly influenced the fruit diameter at site 1 , and fruit length and fruit weight at site 2 . The application of $266 \mathrm{~kg} \cdot \mathrm{ha}^{-1} \mathrm{~K}_{2} \mathrm{O}$ resulted in the highest fruit weight and, at site 2, further increase of $\mathrm{K}$ declined it. Potassium had no significant effect on fruit sugar and acidity. However, at site 2, acid content tended to increase with increased $\mathrm{K}$ applications. Conclusion. Potassium applications at high rates tended to depress most of the growth and yield attributes of cv. Gandul pineapple cultivated on peat soil in Malaysia.

Malaysia / Ana nas comosus / potassium / growth / yields / quality / peat
${ }^{*}$ Correspondence and reprints

Fruits, 2001, vol. 56, p. 45-49 (c) $2001 \mathrm{Cirad} /$ EDP Sciences All rights reserved

Resumen Español, p. 49

\section{Effet du potassium sur la croissance, le rendement et la qualité de l'ananas cultivé sur de la tourbe en zone tropicale.}

Résumé - Introduction. Une expérimentation a été conduite en champ pour étudier les effets du potassium (k) sur la croissance de plantes, ainsi que sur le rendement et la qualité du fruit de l'ananas cultivé sur de la tourbe en zone tropicale. Matériel et méthodes. Six doses de $\mathrm{K}\left(0,266,532,798,1064\right.$ et $\left.1330 \mathrm{~kg} \cdot \mathrm{ha}^{-1} \mathrm{~K}_{2} \mathrm{O}\right)$ ont été appliquées à chacune de deux plantations de cv. Gandul localisées sur deux sites différents. Les dispositifs expérimentaux ont été ceux de blocs en randomisation complète avec trois répétitions. Résultats et discussion. Quel que soit le site, l'application de K n'a eu aucun effet significatif sur la hauteur de la plante et son nombre de feuilles. Le potassium a influencé de manière significative le diamètre de fruit au site 1 et la longueur du fruit et son poids au site 2. L'application de $266 \mathrm{~kg} \cdot \mathrm{ha}^{-1} \mathrm{~K}_{2} \mathrm{O}$ a permis d'obtenir le poids de fruit le plus élevé et, au site 2, des doses supérieures de $\mathrm{K}$ l'ont diminué. Le potassium n'a eu aucun effet significatif sur le sucre et l'acidité du fruit. Cependant, au site 2, la teneur en acide a eu tendance à augmenter avec des applications accrues de K. Conclusion. Les applications de potassium à fortes doses ont tendu à diminuer la plupart des caractéristiques de croissance et de rendement des ananas Gandul cultivés sur sol tourbeux en Malaisie.

Malaisie / Ana nas comosus / potassium / croissance / rendement / qualité / tourbe 


\section{Introduction}

In Malaysia, pineapple is an important fruit. In 1996, about 7,000 ha of land was under pineapple cultivation with a total production of 121,915 $t$ of fresh fruit [1]. Nevertheless, the production is declining and, consequently, in recent times, the export has gone down to a significant amount. Possible causes for this problem include a lack of certain plant nutrients, nutrient imbalances in the soil or in plants due to selective utilization of nutrients by the plant [2]. Generally, in Malaysia, deep peat soil is used for pineapple cultivation and about $97 \%$ of the pineapple holdings are located on peat. Peat soils are deficient in macronutrients and, in some cases, in one or more micronutrient. For pineapples, potassium $(\mathrm{K})$ is the nutrient which is required in greatest quantity. A lack of $\mathrm{K}$ results in poor growth and reduces the fruit yield and quality. On the other hand, excessive application of $\mathrm{K}$ in the soil results in low uptake of $\mathrm{NH}_{4}{ }^{+}, \mathrm{Ca}^{++}$and $\mathrm{Mg}^{++}$[3-5]. Thus, a balanced application of $\mathrm{K}$ not only improves the yield and quality of pineapple, but it also increases the fertilizer use efficiency of other nutrients. Therefore, the present studies were designed to investigate the effects of $\mathrm{K}$ on growth, yield and quality of pineapple grown on peat soil.

\section{Materials and methods}

Field experiments were conducted with the cv. 'Gandul', a pineapple cultivar widely cultivated in Malaysia, at two locations (designated as site 1 and site 2) at the Peninsula (Pineapple) Plantation Estate, Simpang Rengam, Johore, Malaysia. The main difference between the two sites is that site 1 has been under continuous pineapple cultivation for the last 24 years and that of site 2 for about 42 years.

To analyze the physical and chemical properties (table I), soil samples were collected to a depth of $0-15 \mathrm{~cm}$ from both sites.

Five levels of additional potassium application were used at both sites: 266, 532, 798, 1064 and $1330 \mathrm{~kg} \cdot \mathrm{ha}^{-1} \mathrm{~K}_{2} \mathrm{O}$. The control consisted of plots without $\mathrm{K}$ addition. Each plot received a blanket dose of $600 \mathrm{~kg} \cdot \mathrm{ha}^{-1} \mathrm{~N}, 72 \mathrm{~kg} \cdot \mathrm{ha}^{-1} \mathrm{P}_{2} \mathrm{O}_{5}, 32 \mathrm{~kg} \cdot \mathrm{ha}^{-1}$ $\mathrm{CaO}, 24 \mathrm{~kg} \cdot \mathrm{ha}^{-1} \mathrm{MgO}$ and $3.2 \mathrm{~kg} \cdot \mathrm{ha}^{-1} \mathrm{CuO}$. The sources of nitrogen $(\mathrm{N})$, phosphorus $(\mathrm{P})$, potassium $(\mathrm{K})$, calcium $(\mathrm{Ca})$, magnesium $(\mathrm{Mg})$ and copper $(\mathrm{Cu})$ were urea, China phosphate rock, muriate of potash, calcium sulphate, magnesium sulphate and copper sulphate. The experiments were carried out in a randomized complete block design with three replications. Fertilizers (N, P, K, Ca and Mg) were applied in four splits at 2, 4, 6 and 8 months after planting.

\section{Table I.}

Physical and chemical properties of peat soil at two locations (designated as site 1 and site 2) at Johore, Malaysia, where field experiments were conducted to study cv. Gandul pineapple response to K application.

\begin{tabular}{|c|c|c|c|c|c|c|c|}
\hline Location & $\begin{array}{l}\text { Bulk density } \\
\qquad\left(\mathrm{g} \cdot \mathrm{cm}^{3}\right)\end{array}$ & $\begin{array}{c}\text { Ash content } \\
(\%)\end{array}$ & $\begin{array}{l}\text { Porosity } \\
\text { (\%) }\end{array}$ & $\begin{array}{l}\text { Maximum water } \\
\text { holding capacity (\%) }\end{array}$ & $\mathrm{pH}$ & $\begin{array}{c}\text { Organic C } \\
(\%)\end{array}$ & $\begin{array}{l}\text { Total N } \\
\text { (\%) }\end{array}$ \\
\hline Site 1 & 0.20 & 4 & 85 & 492 & 3.45 & 51.9 & 1.39 \\
\hline Site 2 & 0.27 & 15 & 81 & 432 & 3.48 & 47.9 & 1.45 \\
\hline Location & $\begin{array}{c}\text { Extractable P } \\
\left(\mathrm{mg} \cdot \mathrm{kg}^{-1}\right)\end{array}$ & $\begin{array}{l}\text { Exchangeable K } \\
\left(\mathrm{cmol}(+) \cdot \mathrm{kg}^{-1}\right)\end{array}$ & $\begin{array}{l}\text { Exchangeable Ca } \\
\left(\mathrm{cmol}(+) \cdot \mathrm{kg}^{-1}\right)\end{array}$ & $\begin{array}{l}\text { Exchangeable } \mathrm{Mg} \\
\left(\mathrm{cmol}(+) \cdot \mathrm{kg}^{-1}\right)\end{array}$ & \multicolumn{2}{|c|}{$\begin{array}{l}\text { Extractable } \mathrm{Cu} \\
\left(\mathrm{mg} \cdot \mathrm{kg}^{-1}\right)\end{array}$} & $\begin{array}{l}\text { Sation Exchange } \\
\text { Capacity } \\
\left(\mathrm{cmol}(+) \cdot \mathrm{kg}^{-1}\right)\end{array}$ \\
\hline Site 1 & 53.7 & 4.70 & 1.90 & 0.38 & \multicolumn{2}{|c|}{30} & 107.5 \\
\hline Site 2 & 51.5 & 3.04 & 1.20 & 0.22 & \multicolumn{2}{|c|}{49} & 114.7 \\
\hline
\end{tabular}


Copper was applied in a single spray at 2 months after planting.

Ground suckers of about $40 \mathrm{~cm}$ in length were planted. A plantation of 62,117 plants. ha $^{-1}$ was maintained with a double-row planting system $(76.2 \mathrm{~cm} \times 55.9 \mathrm{~cm} \times$ $24.4 \mathrm{~cm}$ ). The unit plot size was $18.0 \mathrm{~m} \times$ $2.64 \mathrm{~m}$.

Flowerinduction was achieved 10 months after planting. The fruits were harvested when one-third ripe which was achieved $155 \mathrm{~d}$ after flower induction.

The plant height and leaf number were measured at forcing time (10 months after planting) and fruit yield and quality characteristics were recorded at harvest. Fruit sugar were measured as Brix \% with a hand held refractometer and acidity as \% citric acid equivalent. The analysis of variance was accomplished following the statistical package of MSTAT (MSTAT-C, Michigan State University) and the mean values were compared by Duncan's New Multiple Range test (DMRT) at a $5 \%$ level of significance.

\section{Results and discussion}

\subsection{Plant growth characteristics}

The plant heights of cv. Gandul pineapple ranged from 109.4 to $115 \mathrm{~cm}$ at site 1 and from 103.6 to $108.6 \mathrm{~cm}$ at site 2 (table II). This characteristic was not influenced significantly with the application of potassium. The same was observed with the leaf number which ranged from 51 to 56 at site 1 and from 55 to 58 at site 2 . In a field trial, Selamat and Ramlah [6] noted a significant effect of $\mathrm{K}$ on plant height but nothing on the leaf number in the same cultivar, at 9 months after planting on deep peat soil.

\subsection{Fruit yield characteristics}

The fruit yield attributes of pineapple indicated that there were significant effects of $\mathrm{K}$ on fruit diameter at site 1 and on fruit length and fruit weight at site 2 .

At site 1, the highest fruit diameter resulted from the application of $798 \mathrm{~kg} \cdot \mathrm{ha}^{-1} \mathrm{~K}_{2} \mathrm{O}$

Table II.

Effect of different potassium doses on growth, yield and quality of cv. Gandul pineapple grown on peat soil at two sites (Johore, Malaysia).

\begin{tabular}{|c|c|c|c|c|c|c|}
\hline $\begin{array}{l}\text { Potassium } \\
\left(\mathrm{kg} \cdot \mathrm{ha} \mathrm{a}^{-1} \mathrm{~K}_{2} \mathrm{O}\right)\end{array}$ & $\begin{array}{l}\text { Plant height } \\
\qquad(\mathrm{cm})\end{array}$ & Leaf number & $\begin{array}{l}\text { Fruit length } \\
\qquad(\mathrm{cm})\end{array}$ & $\begin{array}{l}\text { Fruit diameter } \\
\qquad(\mathrm{cm})\end{array}$ & $\begin{array}{l}\text { Fruit sugar } \\
\text { (Brix \%) }\end{array}$ & $\begin{array}{c}\text { Fruit acidity } \\
\text { (\%) }\end{array}$ \\
\hline \multicolumn{7}{|l|}{ Site 1} \\
\hline 0 & 109.4 & 55.2 & 16.8 & $12.3 \mathrm{c}$ & 10.1 & 0.60 \\
\hline 266 & 114.9 & 53.8 & 17.1 & $12.6 \mathrm{bc}$ & 10.2 & 0.65 \\
\hline 532 & 110.6 & 53.2 & 17.1 & $12.7 \mathrm{abc}$ & 10.3 & 0.66 \\
\hline 798 & 114.0 & 50.8 & 6.9 & $13.0 \mathrm{a}$ & 10.3 & 0.65 \\
\hline 1064 & 113.3 & 55.9 & 17.0 & $12.8 \mathrm{ab}$ & 10.1 & 0.67 \\
\hline 1330 & 111.6 & 53.2 & 16.6 & $12.7 \mathrm{abc}$ & 10.1 & 0.66 \\
\hline \multicolumn{7}{|l|}{ Site 2} \\
\hline 0 & 108.6 & 55.1 & $16.1 \mathrm{ab}$ & 11.7 & 8.9 & 0.57 \\
\hline 266 & 105.7 & 55.0 & $16.6 \mathrm{a}$ & 11.8 & 8.9 & 0.58 \\
\hline 532 & 104.0 & 55.3 & $16.4 \mathrm{a}$ & 11.4 & 9.1 & 0.58 \\
\hline 798 & 106.9 & 57.6 & $16.5 \mathrm{a}$ & 11.7 & 9.3 & 0.63 \\
\hline 1064 & 103.6 & 55.5 & $16.3 \mathrm{a}$ & 11.9 & 9.2 & 0.64 \\
\hline 1330 & 105.7 & 55.0 & $15.8 \mathrm{~b}$ & 11.8 & 9.1 & 0.64 \\
\hline
\end{tabular}

Means within a column followed by the same letter are not significantly different at $5 \%$ level by Duncan's New Multiple Range Test. 
and similar data were obtained with the rates of 532, 1064 and $1330 \mathrm{~kg} \cdot \mathrm{ha}^{-1} \mathrm{~K}_{2} \mathrm{O}$. The lowest fruit diameters were produced in the untreated plots.

At site 2, the langest fruit lengths resulted from the application of $266 \mathrm{~kg} \cdot \mathrm{ha}^{-1} \mathrm{~K}_{2} \mathrm{O}$ and were similar to the other levels, except for the highest $\mathrm{K}$ application level of $1330 \mathrm{~kg} \cdot \mathrm{ha}^{-1} \mathrm{~K}_{2} \mathrm{O}$ which significantly induced the lowest fruit length. In another trial, Selamat and Ramlah [6] did not find any change in fruit length for the Gandul cv. cultivated in peat soil. In fact, potassium applications seemed to have depressed the fruit length at both sites. Other works [7-9] reported that high dressing of $\mathrm{K}$ had antagonistic effect on the uptake of $\mathrm{Mg}$ and $\mathrm{NH}_{4}-\mathrm{N}$. Thus, the highest $\mathrm{K}$ application levels might have resulted in a depressing effect on fruit length through its inhibitory effect on the plant normal growth and development.

At site 1, there was no significant effect of $\mathrm{K}$ on the pineapple fruit weights but the characteristic tended to decline with increased $\mathrm{K}$ application. The fruit weight varied from 1.19 to $1.26 \mathrm{~kg}$ at this site. At site 2 , the fruit weight declined linearly $\left(\mathrm{R}^{2}=0.75^{*}\right)$ with increased $\mathrm{K}$ application (figure 1). The highest $\mathrm{K}$ application resulted in the lowest fruit weight. Similar crop responses were observed in other studies in both mineral and peat soils. In most cases, $\mathrm{K}$ applications at low doses favoured fruit weight $[6,10,11]$. The lower fruit weight with high rates of $\mathrm{K}$ might be related to the reduced uptake of $\mathrm{NH}_{4}-\mathrm{N}$ and other cations, as there is an interrelationship between the plant $\mathrm{NH}_{4}, \mathrm{Ca}, \mathrm{Mg}$ and $\mathrm{K}$ levels [7, 12].

Figure 1.

Effect of different levels of potassium on fruit weight of cv. Gandul pineapple depending on the location of the experiments designated as 'site 1' and 'site 2' (Johore, Malaysia).

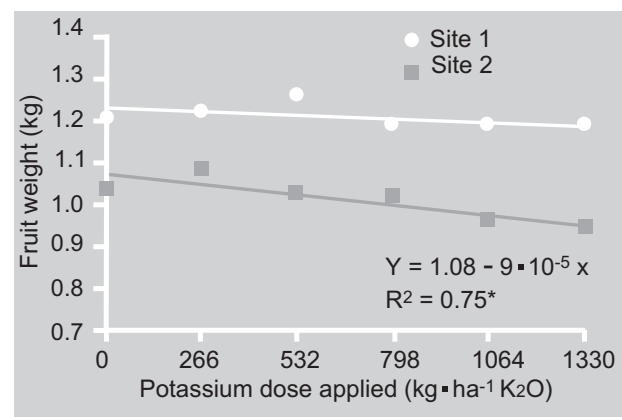

\subsection{Fruit quality characteristics}

At both sites of the studies, fruit qualities such as the fruit sugar and acidity were not significantly influenced by the application of $\mathrm{K}$. Howewer, sugar contents varied with a narrow range of 10.1 to $10.3 \%$ at site 1 , and from 8.9 to $9.3 \%$ at site 2 (table II).

Results regarding the effets of $\mathrm{K}$ on fruit sugar in pineapples are not consistent. Sugar content in Singapore Spanish variety was found to have significantly increased with K application [11, 13, 14], while it was significantly reduced in the cv. Gandul on peat soil [6]. On the other hand, Su [15] found no significant effect on fruit sugar with the increased levels of $\mathrm{K}$ on mineral soil.

Although $\mathrm{K}$ had no significant influence on the acid content of fruits, fruit acidity tended to increase with increased $\mathrm{K}$ rates. Fruits produced from the unfertifized plots were less acid than those of the plants which received $\mathrm{K}$ applications. The acid content had a $0.60-0.67 \%$ range at site 1 and $0.57-0.64 \%$ range at site 2 . Previous studies [6, 11, 14] showed that acidity of fruits increased with increased $\mathrm{K}$ levels in different pineapple cultivars on both peat and mineral soils.

\section{Conclusion}

With the cv. Gandul pineapple cultivated on deep peat soil, potassium had not any significant influence on plant growth and fruit quality characteristics. Application of 266-532 kg.ha-1 $\mathrm{K}_{2} \mathrm{O}$ produced the heaviest fruits and $\mathrm{K}$ rates beyond these levels tended to cause depressed fruit weights, plant growth and other yield characteristics.

\section{References}

[1] Anonymous, Statistics on commodities, MPIM (Ministry of Primary Industries Malaysia), Kuala Lumpur, Malaysia, 1997, pp. 113-118. 
[2] Verawudh J., Effect of micronutrients on growth, nutrient contents in D-leaf and yield of pineapple, in: Bartholomew D.P., Rohrbach K.G. (Eds), Proceedings of the first international pineapple symposium, Honolulu, Hawaii, 1993, pp. 241-246.

[3] Ludders P., Effects of time and amount of nutrient additives on nutrient status and distribution and on fruit quality, in: Atkinson D., Jackson J.E., Sharples R.O., Waller W.M. (Eds), Mineral nutrition of fruit trees, Butterworths, London, 1980, pp. 111-121.

[4] Kirkby E.A., Maximizing calcium uptake by plants, Commun. Soil Sci. Plant Anal. 10 (1979) 89-113.

[5] Mengel K., Haeder H.E., Effect of potassium supply on the rate of phloem sap exudation and the composition of phloem sap of Ricinus communis, Plant Physiol. 59 (1977) 282-284.

[6] Selamat M.M., Ramlah M., The response of pineapple cv. Gandul to nitrogen, phosphorus and potassium on peat soil in Malaysia, in: Bartholomew D.P., Rohrbach K.G. (Eds), Proceedings of the first international pineapple symposium, Honolulu, Hawaii, 1993, pp. 247-254.

[7] Ohno T., Grunes D.L., Potassium-magnesium interactions affecting nutrient uptake by wheat forage, Soil Sci. Soc. Am. J. 49 (1985) 685-690.

[8] Wilkinson S.R., Effect of soil application of magnesium and other minerals on plant magnesium content, in: Fontenot J.P. (Ed.), Role of magnesium in animal nutrition, Virginia Polytechnic Institute Press, Blacksburg, VA, 1983.

[9] Sideris C.P., Young H.Y., Effects of different amounts of potassium on growth and ash constituents of Ananas comosus (L) Merr., Plant Physiol. 20 (1945) 609-630.

[10] Chadha K.L., Subramanian T.R., Melanta K.R., Effect of varying levels of N, P and K on growth, yield and quality in variety Queen, Indian J. Hort. 33 (1976) 224-226.

[11] Tay T.H., Comparative study of different types of fertilizer as sources of nitrogen, phosphorus and potassium in pineapple cultivation, Trop. Agric. (Trinidad) 49 (1972) 51-59.

[12] Hannaway D.B., Bush L.P., Leggett J.E., Plant nutrition: magnesium and hypomagnesium in animals, Kentucky Agric. Expt. Stn. Bull., 1980, $716 \mathrm{p}$.

[13] Tay T.H., Wee P.C., Chong W.S., The nutritional requirements of pineapple [Ananas comosus (L) Merr. var. Singapore Spanish] on peat soil in Malaya. 1. Effect of nitrogen, phosphorus and potassium on yield, sugar and acid content of the fruit, Malaya Agric. J. 46 (1968) 458-468.

[14] Kannapathy V., Leaf analysis in relation to yield and quality of pineapples, Malaya Agric. J. 49 (1958) 18-26.

[15] Su N.R., The response of pineapples to the application of potassium chloride, J. Agric. Assoc. China. 22 (1958) 27-50.

\section{Efecto del potasio sobre el crecimiento, rendimiento y calidad de la piña cultivada en turba tropical.}

Resumen - Introducción. Se realizó un experimento en campo para estudiar los efectos del potasio $(\mathrm{K})$ en el crecimiento de las plantas y en el rendimiento y calidad del fruto de la piña cultivada en turba en la zona tropical. Material y métodos. Se aplicaron seis dosis de $\mathrm{K}$ $\left(0,266,532,798,1064\right.$ y $\left.1330 \mathrm{~kg} \cdot \mathrm{ha}^{-1} \mathrm{k}_{2} \mathrm{O}\right)$ en dos plantaciones de cv. Gandul localizadas en un sitio 1 y en un sitio 2. Se empleó un diseño experimental de bloques al azar completo con tres repeticiones. Resultados y discusión. La aplicación de K, en cualquiera de los sitios, no tuvo ningún efecto significativo en la altura de la planta y el número de hojas. El potasio influyó de forma significativa en el grosor del fruto en el sitio 1 y en la longitud y peso en el sitio 2. La aplicación de $266 \mathrm{~kg} \cdot \mathrm{ha}^{-1} \mathrm{~K}_{2} \mathrm{O}$ permitió obtener el peso más alto de los frutos $\mathrm{y}$, en el sitio 2, las dosis superiores de $\mathrm{K}$ lo disminuyeron. El potasio no tuvo ningún efecto significativo en el azúcar y la acidez del fruto. Sin embargo, en el sitio 2, el contenido en ácido manifestó una tendencia a aumentar con el incremento de las aplicaciones de K. Conclusión. Las aplicaciones de potasio a altas dosis favorecieron la disminución de la mayoría de características de crecimiento y rendimiento de piñas gandul cultivadas en suelo de turba en Malaisia.

Malasia / Ananas Comosus / potasio / crecimiento / rendimiento / calidad / turba 